\title{
A systematic review of group therapy programs for smoking cessation in Asian countries
}

\author{
Rashidi Mohamed', Christopher Bullen², Farizah Mohd Hairi ${ }^{3}$, Amer Siddiq Amer Nordin ${ }^{4,5}$
}

\begin{abstract}
INTRODUCTION Tobacco causes more than 8 million deaths each year. Behavioral interventions such as group therapy, which provides counselling for smoking cessation, can be delivered in group form and smokers who receive cessation counselling are more likely to quit smoking compared to no assistance. We review the evidence of group-based counselling for smoking cessation for smokers in Asian countries.

METHODS The review aims to determine the availability of group-based therapy for smoking cessation in Asian countries. The outcome measured was abstinence from smoking following group therapy. Electronic database searches in PubMed, OVID Medline, SCOPUS, Google Scholar, and PsycINFO, using keywords such as: 'smoking', 'cigarette', 'tobacco', 'nicotine', 'group therapy' and 'cessation' (smok*, *cigarette*, tobacco, nicotine, group therap*, cessation) were used. The results were reported following PRISMA and PROSPERO guidelines. Review Manager was used for data analysis.

RESULTS A total of 21251 records were retrieved for screening the abstracts. In all, 300 articles for review were identified and assessed for eligibility. Nine articles, including Cochrane reviews, randomized control trials, cohort, observational and cross-sectional studies, were included in the final review. There were three observational qualitative studies, two prospective cohort studies, two crosssectional studies, one non-randomized quasi-experimental study and a single cluster-randomized, controlled trial. Group therapy was found to significantly increase the abstinence rate. Group therapy provided at the workplace, smoking cessation services, availability of pharmacotherapy, and socioeconomic status, appear to be key factors determining success.

CONCLUSIONS Evidence of the use of group therapy for smoking cessation in Asian countries is still lacking despite publications in the Western population showed that group therapy was effective. Further research on group-based interventions for smoking cessation in Asian countries is required and direct one-to-one comparisons between group therapy and individual therapy for smokers who want to quit smoking, are needed.
\end{abstract}

\author{
AFFILIATION \\ 1 Department of Family \\ Medicine, Faculty of \\ Medicine, National University \\ of Malaysia, Bangi, Malaysia \\ 2 National Institute for \\ Health Innovation, School of \\ Population Health, University \\ of Auckland, Auckland, New \\ Zealand \\ 3 Department of Social and \\ Preventive Medicine, Faculty \\ of Medicine, Universiti \\ Malaya, Kuala Lumpur, \\ Malaysia \\ 4 Department of \\ Psychological Medicine, \\ Faculty of Medicine, Universiti \\ Malaya, Kuala Lumpur, \\ Malaysia \\ 5 University of Malaya Centre \\ for Addiction Science Studies, \\ Universiti Malaya, Kuala \\ Lumpur, Malaysia \\ CORRESPONDENCE TO \\ Amer Siddiq Amer Nordin. \\ Department of Psychological \\ Medicine, Faculty of \\ Medicine, Universiti Malaya, \\ Kuala Lumpur, 50603, \\ Malaysia.E-mail: amersiddiq@ \\ um.edu.my
}

KEYWORDS smoking, group therapy, nicotine, tobacco, cessation

Received: 2 April 2021

Revised: 26 May 2021

Accepted: 8 July 2021

\section{INTRODUCTION}

Tobacco causes more than 8 million deaths each year worldwide from long-term first hand and secondhand effects of cigarette smoking ${ }^{1}$. Smoking is the act of inhaling and exhaling the fumes of burning plant material. A variety of plant materials are smoked but the act is most commonly associated with tobacco smoked in cigarettes ${ }^{2}$. It is reported that $80 \%$ of the total population of smokers worldwide are in low- and middle-income countries ${ }^{3}$. Despite this, smokers in poor countries had no less interest in quitting smoking ${ }^{4}$. Smoking cessation treatment is 
a vital element in the MPOWER (Monitor tobacco use; Protect people from tobacco smoke; Offer help to quit tobacco use; Warn about dangers of tobacco; Enforce bans on tobacco advertising, promotion and sponsorship; Raise taxes on tobacco) package of tobacco control measures recommended by the World Health Organization (WHO). Most tobacco users want to quit, but only a handful receive support and help to overcome their dependence and the healthcare systems are responsible for treating tobacco dependence. Programs provided by the healthcare system must include tobacco cessation advice, access to medicine, and quitline ${ }^{5}$.

Stopping smoking leads to immediate and longterm benefits such as reduction of risk of stroke among high-risk patients ${ }^{6}$ and premature cardiac deaths among patients ${ }^{7,8}$. The global prevalence of current male smokers is $25 \%$ with half of the smokers from Asian countries (China, India, Indonesia). The economic cost of smoking is at a staggering US $\$ 2$ trillion, as most of the cost involves loss of productivity due to smoking-related disease ${ }^{9}$. This amount has not included other collateral damages such as secondhand smoking, agricultural loss of biodiversity, soil erosion, and fire hazards ${ }^{10}$. ASEAN (Association of Southeast Asian Nations) countries have approximately 122.4 million smokers, which is equivalent to $10 \%$ of total smokers worldwide ${ }^{11}$. Indonesia has the highest number of smokers in Asian countries ${ }^{11}$. Asian countries are the major contributors of the total number of smokers worldwide. The number of male smokers is much higher than female smokers. In 2019, according to a study by Yang et al. ${ }^{5,9,12}$, the global prevalence of current smoking in men was $25 \%$, and nearly half of the smokers were from China, India, and Indonesia. Among the Asian countries, Indonesia has the highest prevalence of male smokers $(76 \%)$ followed by Laos $(57 \%)$, China (48\%), Vietnam (47\%), Cambodia (44\%), Malaysia (43\%), Philippines (43\%), Pakistan (42\%), Thailand (41\%), Bangladesh (40\%), Nepal (37\%), Japan (34\%), Myanmar (32\%), Singapore (28\%), Sri Lanka (28\%), South Korea (22\%), and India (20\%).

A total of about 1.3 billion cigarettes are smoked every day in ASEAN countries. High-income Asian countries like Japan and South Korea have a similar smoking prevalence compared to other developed countries such as Germany. The overall prevalence of smoking in Japan is $19.3 \%{ }^{13}$, with predominantly male smokers $(26.6 \%)$ while $9.3 \%$ are female smokers ${ }^{11}$. The overall prevalence of smokers in South Korea with predominantly male smokers did not differ dramatically compared to Japan (19.9\% vs $19.3 \%)$.

In accordance to the World Health Organization Framework Convention on Tobacco Control (WHO FCTC) Article 14, governments should make smoking cessation easily accessible for would-be quitters. Unfortunately, only a quarter of the 181 WHO FCTC signatories have designated budgets for smoking cessation ${ }^{14}$. Tobacco control interventions have had a positive outcome in high-income Asian countries such as Japan, South Korea and Singapore, but the results have not been replicated in low- and middle-income countries such as China and India ${ }^{15}$. Smoking cessation services in Asian countries vary widely, from almost none, to quit advice at healthcare facilities, to brief intervention, and counselling with pharmacotherapy. In some countries, private pharmacies provide advice on how to quit smoking and in others, telephone quitlines are available ${ }^{16}$. Health workers who have undergone training for smoking cessation are more likely to provide smoking cessation counselling for their patients ${ }^{17}$. People who receive counselling are more likely to quit smoking compared to minimal intervention ${ }^{18}$. Pharmacotherapy, such as nicotine replacement therapy and varenicline, for smoking cessation helps smokers to overcome withdrawal symptoms during the smoking abstinence period, and is of proven effectiveness ${ }^{19}$. It has been estimated that simply providing nicotine replacement therapy (NRT) with the effectiveness of even $1 \%$ above baseline in low- and middle-income countries could save nearly 3 million lives over the next century ${ }^{20}$. However, uptake of NRT is low as it is too expensive for many smokers in poor Asian countries, and even when subsidized the uptake of NRT is low ${ }^{19}$. Asian cultures are typically collective and family centered. Hence, group-based social support techniques such as family therapy or 'buddy' systems may be of greater interest to smokers than individual treatment ${ }^{21}$. Group-based interventions offer patients the opportunity for social learning, for example sharing knowledge and skills about behavioral techniques for smoking cessation, generate emotional experiences and provide mutual support $^{22}$. Evidence has also shown that group therapy for smoking cessation had demonstrated preliminary 
efficacy and feasibility of group-based smoking cessation treatment with pharmacotherapy in a special population $^{23}$.

Furthermore, group-based approaches may be a more efficient way of reaching and supporting the many millions of Asian smokers who need support to quit than current individually targeted approaches. In some settings, group treatment has been shown to be more effective than no intervention or minimal intervention and about as effective as an intensive individual intervention ${ }^{24}$ but more affordable ${ }^{25}$. In this systematic review, our objective was to examine the evidence on the availability of group therapy as a behavioral intervention for smoking cessation for smokers who want to quit smoking in Asian countries and the documented abstinence after a quit attempt.

\section{METHODS}

We conceptualized the review by setting various objectives related to the subject of behavioral support, particularly group therapy, in Asian countries. The objectives were to determine the abstinence rate among patients in group therapy as a behavioral intervention for smoking cessation and to compare the effectiveness of group-based therapy for smoking cessation available for smokers to quit smoking in Asian countries. Abstinence is defined as no use of combustible cigarettes, without considering the use of other tobacco or alternative products ${ }^{26}$ and not smoking for 3 to 6 months from the quit date. The study population in this systematic review are smokers who have joined a group therapy as a behavioral intervention for smoking cessation conducted in Asian countries with abstinence from smoking as the outcome of interest.

The behavioral intervention has been frequently used to help smokers to quit smoking but the effectiveness and content of the intervention vary substantially. To identify the eligibility of the studies included in the systematic review, we searched and reviewed the articles with the keywords: 'smoking', 'cigarette', 'tobacco', 'nicotine', 'group therapy', and 'cessation' (smok*, *cigarette*, tobacco, nicotine, group therap*, cessation). We selected studies to be included in this systematic review based on inclusion and exclusion criteria. The key criteria used during the assessment of the type of study selected in this systematic review were: recruitment, treatment allocation, randomization, response rate, outcome measurement, levels of missing data, and how missing data were addressed. In our systematic review, studies with participants who were cigarette smokers aged $\geq 18$ years, articles from 1 January 2004 to 6 July 2020 published in English only were included. The databases searched were PubMed, OVID Medline, SCOPUS, Google Scholar and PsycINFO. We also looked if the reported smoking cessation abstinence measurement of cessation used biochemical validation at the reported time point. Studies with incomplete data or estimates were excluded from the analysis. Studies with low grade of evidence were included only after discussion among the researchers. A third reviewer was consulted when an agreement could not be reached between the two researchers. Various study designs including systematic reviews, qualitative studies, cross-sectional observational studies, longitudinal observational studies, prospective randomized controlled trials, and other experimental studies, were evaluated for inclusion in this systematic review.

A variety of behavior therapies ranging in complexity from simple advice offered by a physician or other healthcare provider or a much more extensive therapy have been shown to be efficacious for tobacco smoking cessation. The success rate for abstinence from smoking increases when behavioral therapy is combined with pharmacotherapy. A behavioral intervention involves discussion, encouragement, advice and other modalities to help to achieve behavioral change ${ }^{19}$.

Group therapy is defined as the process of giving and receiving assistance, from individuals with similar conditions or circumstances, to achieve recovery in a group form. The group of people in group therapy voluntarily gather to receive support and provide support by sharing knowledge, experiences, coping strategies, and offering understanding towards smoking cessation intervention. The most common behavioral intervention for smoking cessation was individual therapy. Individual therapy is a face-toface session with a trained therapist that focuses on behavioral change, which also incorporates motivational interviewing ${ }^{27}$. The individual intervention involves self-exploration and identifying ambivalence so that resolutions can be determined for effective behavioral change ${ }^{28}$. 
Strategies for helping smokers to quit include behavioral counselling to enhance motivation and to support attempts to quit and pharmacological intervention to reduce nicotine reinforcement and the withdrawal symptoms of cessation of tobacco use $^{29}$. We have included all the studies that fulfilled the inclusion and exclusion criteria. We evaluated the studies included in the systematic review by looking at the nature of behavioral support provided such as motivation to quit smoking, mode of delivery of the behavioral support, behavioral intervention service provider, and presence and type of pharmacotherapy provided.

The study domain was behavioral intervention (group therapy) for the treatment of nicotine addiction secondary to cigarette smoking. The outcome measure was abstinence from smoking following different types of behavioral interventions with or without pharmacotherapy. Abstinence was defined as not smoking for 3 to 6 months from the quit date. The results of the systematic review are reported following both the Preferred Reporting Items for Systematic Reviews and Meta-Analysis (PRISMA) ${ }^{30}$ and the International Prospective Register of Systematic Review (PROSPERO) ${ }^{31}$ guidelines. Articles were excluded if other forms of tobacco were involved, such as chewing tobacco, electronic devices such as e-cigarettes, and other drug use such as cannabis.

Various study designs selected including systematic reviews, qualitative studies, cross-sectional observational studies, longitudinal observational studies, prospective randomized controlled trials, and other experimental studies, and the intervention effect (group therapy for smoking cessation) was measured by before and after treatment estimates that provided important information on the outcome. Review Manager (RevMan) software (version 5.4, Copenhagen: Nordic Cochrane Centre, Cochrane Collaboration) was used for data analysis ${ }^{32}$. We used the random-effects model. Heterogeneity between studies was assessed using the $\mathrm{I}^{2}$ test. An $\mathrm{I}^{2}$ value of $0 \%$ indicates no observed heterogeneity, and larger values show increasing heterogeneity ( $75 \%$ or greater considered substantial heterogeneity).

\section{RESULTS}

After the screening we identified a total of 300 articles for review (Figure 1). They were assessed for eligibility by checking against the inclusion and exclusion criteria, leaving 9 articles for the final systematic review. The selected journals were studies conducted in Asian countries, published in English, with full-text article available. All the selected studies for this systematic review fulfilled the inclusion criteria. Table 1 shows that the nine studies in the systematic review were in middle- and high-income Asian countries (Malaysia, India, China, Taiwan, Iran, Mongolia, Pakistan, Japan, and South Korea) ${ }^{6,14,24,33-38}$. Five studies were conducted in healthcare centers with smoking cessation clinics, three at universities, and one at a factory (a workplace intervention). The original authors were contacted to obtain further information for studies where details related to the systematic review were missing. There were three observational qualitative studies, two prospective cohort studies, two cross-sectional studies, one nonrandomized quasi-experimental study, and a single cluster-randomized, controlled trial. The type of intervention (pharmacotherapy + behavioral therapy, pharmacotherapy only, behavioral therapy, or no intervention) varied between the selected studies. Six studies provided pharmacotherapy and behavioral intervention and three provided behavioral support. Four studies described using pharmacotherapy (nicotine replacement therapy) and behavioral therapy, and only one study described the use of bupropion. Behavioral therapy only, was provided in three studies. The studies included in the systematic review included smokers who smoked at least one cigarette per day with a mean of 10-22.1 cigarettes smoked per day, and low to high level of nicotine dependence. (Figure 1).

Two studies involving group therapy as behavioral intervention in the smoking cessation treatment compared outcomes with usual care practice. In a pooled analysis of these studies using the randomeffects model, the intervention group significantly increased the abstinence rate (Figure 2). A total of 560 of $1266(44.2 \%)$ patients who received intervention had quit smoking at 6 months compared with 56 of 661 $(8.5 \%)$ patients who received usual care $(\mathrm{RR}=5.55$; 95\% CI: 3.75-8.22, p<0.001). In the study involving smokers who had tuberculosis and had undergone group therapy as smoking cessation behavioral support, the number of participants included in the final analysis was equal and comparable between the 
Figure 1. Flow chart of search strategy results of electronic database search which include Google Scholar, PubMed, Scopus, PsycINFO, Ovid Medline from years 2004-2020

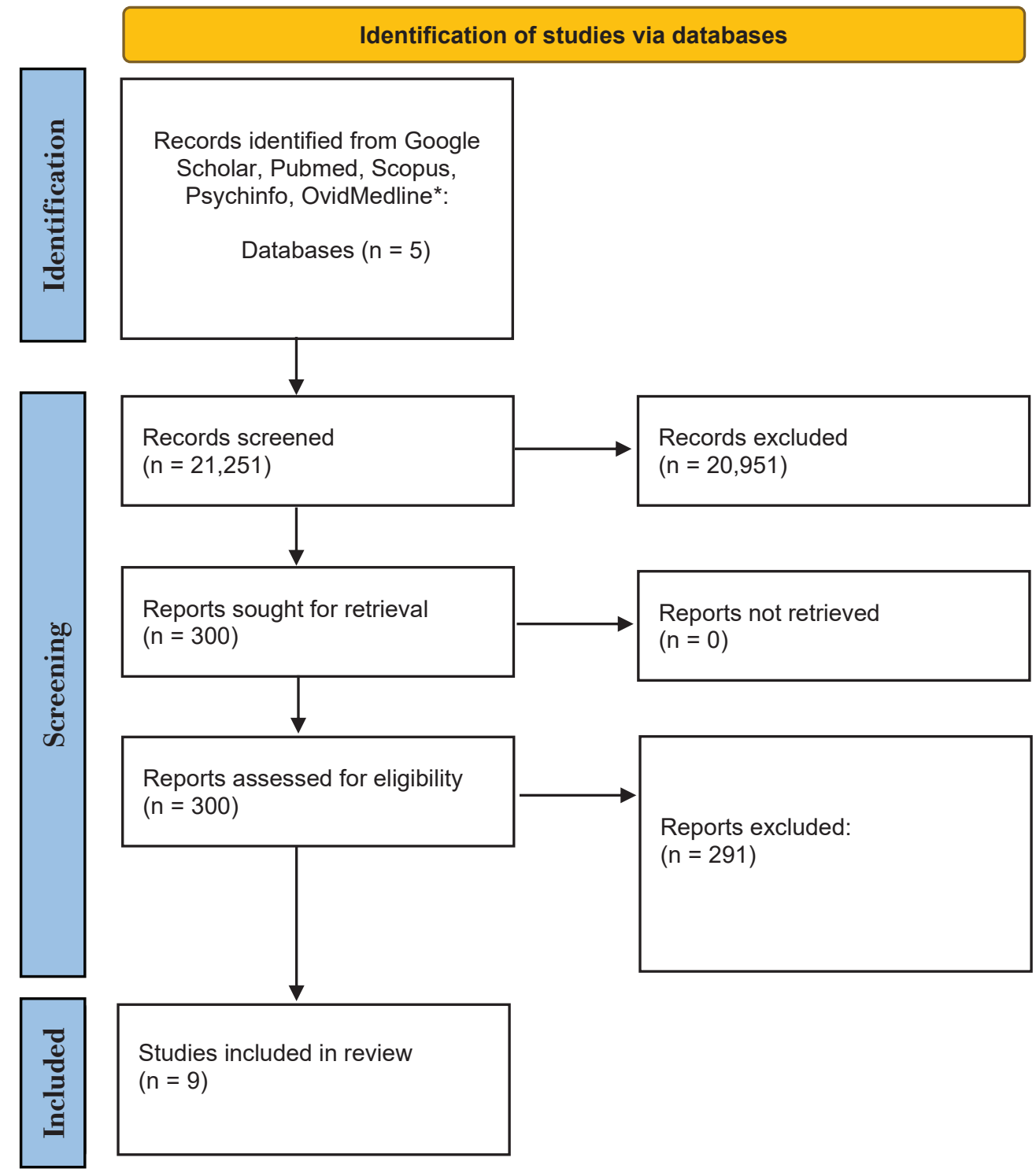


Table 1. Summary of the data extracted from articles identified in systematic review comparing group and other smoking cessation interventions services among Asian countries

\begin{tabular}{|c|c|c|c|c|c|c|c|c|c|}
\hline & $\begin{array}{l}\text { First author, } \\
\text { year of } \\
\text { publication } \\
\text { and country } \\
\text { where } \\
\text { study was } \\
\text { conducted }\end{array}$ & $\begin{array}{c}\text { Role of group } \\
\text { therapy }\end{array}$ & $\begin{array}{l}\text { Types of } \\
\text { study }\end{array}$ & $\begin{array}{c}\text { Treatment type/ } \\
\text { comparison }\end{array}$ & Details of methodology & $\begin{array}{l}\text { Number of } \\
\text { participants }\end{array}$ & Results & Conclusion & $\begin{array}{l}\text { Quality } \\
\text { of } \\
\text { evidence } \\
\text { (Grade) }\end{array}$ \\
\hline 1 & $\begin{array}{l}\text { Maarof } \\
2016 \\
\text { Malaysia }\end{array}$ & $\begin{array}{l}\text { Group therapy } \\
\text { as a behavioral } \\
\text { intervention } \\
\text { for smoking } \\
\text { cessation }\end{array}$ & $\begin{array}{l}\text { Qualitative } \\
\text { Observational } \\
\text { study }\end{array}$ & $\begin{array}{l}\text { Group therapy } \\
\text { for two separate } \\
\text { groups }\end{array}$ & $\begin{array}{l}\text { Evaluating a developed module for } \\
\text { smoking cessation in a single focus } \\
\text { group discussion. Suitability of the } \\
\text { module was assessed by using a } \\
\text { questionnaire with a Likert-scale and } \\
\text { behavioral issues that were identified } \\
\text { as themes were included in developed } \\
\text { module. }\end{array}$ & $\begin{array}{l}8 \text { (4 each } \\
\text { group) }\end{array}$ & $\begin{array}{l}\text { Seven major themes: reasons } \\
\text { for regular smoking, reasons } \\
\text { for quitting, comprehending } \\
\text { smoking characteristics, quit } \\
\text { attempt experiences, support and } \\
\text { encouragement, learning new skills } \\
\text { and behavior, and preparing for } \\
\text { lapse/relapse or difficult situations. }\end{array}$ & $\begin{array}{l}\text { Findings indicate that components } \\
\text { developed were important and } \\
\text { could be applied in delivering group } \\
\text { behavioral therapy. }\end{array}$ & Low \\
\hline 2 & $\begin{array}{l}\text { Baigalmaa } \\
2006 \\
\text { Mongolia }\end{array}$ & $\begin{array}{l}\text { Group therapy } \\
\text { as a behavioral } \\
\text { intervention } \\
\text { for smoking } \\
\text { cessation } \\
\text { Behavioral } \\
\text { therapy only }\end{array}$ & $\begin{array}{l}\text { Prospective } \\
\text { cohort study }\end{array}$ & $\begin{array}{l}\text { Group therapy } \\
\text { and face to face } \\
\text { with follow- } \\
\text { up telephone } \\
\text { consultation }\end{array}$ & $\begin{array}{l}\text { Each group consisted of } 12-16 \\
\text { participants. Training included } \\
\text { information on tobacco or health, } \\
\text { needs to quit, ways to overcome } \\
\text { smoking behavior, problem solving } \\
\text { and individual plans for behavioral } \\
\text { modification, adjusting to become non- } \\
\text { smoker and setting a quit date. } \\
\text { Participants were followed up by } \\
\text { telephone at } 1,3,6 \text {, and } 12 \text { months. } \\
\text { Cessation program and follow-up } \\
\text { period, educational materials and } \\
\text { consultations were provided for the } \\
\text { participants. }\end{array}$ & 517 & $\begin{array}{l}\text { The cessation rate of } 2 \text { years during } \\
\text { the follow-up period gradually } \\
\text { decreased from } 70.6 \% \text { at the first } \\
\text { month to } 65 \% \text { at the } 12 \text { th month. } \\
\text { Behavior modification among heavy } \\
\text { smokers after } 12 \text { months was } 47 \% \text {. }\end{array}$ & $\begin{array}{l}\text { Group counselling for smoking } \\
\text { cessation is effective for smokers } \\
\text { with an intention to quit smoking. } \\
\text { Group programs were more } \\
\text { effective for helping people to stop } \\
\text { smoking than being given self-help } \\
\text { materials without } \\
\text { face-to-face instruction and group } \\
\text { support. }\end{array}$ & Moderate \\
\hline
\end{tabular}


Table 1. Continued

\begin{tabular}{|c|c|c|c|c|c|c|c|c|c|}
\hline & $\begin{array}{l}\text { First author, } \\
\text { year of } \\
\text { publication } \\
\text { and country } \\
\text { where } \\
\text { study was } \\
\text { conducted }\end{array}$ & $\begin{array}{c}\text { Role of group } \\
\text { therapy }\end{array}$ & $\begin{array}{l}\text { Types of } \\
\text { study }\end{array}$ & $\begin{array}{l}\text { Treatment type/ } \\
\text { comparison }\end{array}$ & Details of methodology & $\begin{array}{l}\text { Number of } \\
\text { participants }\end{array}$ & Results & Conclusion & $\begin{array}{l}\text { Quality } \\
\text { of } \\
\text { evidence } \\
\text { (Grade) }\end{array}$ \\
\hline 3 & $\begin{array}{l}\text { Huang } \\
2005 \\
\text { Taiwan }\end{array}$ & $\begin{array}{l}\text { Short-term } \\
\text { group support } \\
\text { for smoking } \\
\text { cessation } \\
\text { Pharmacotherapy } \\
\text { and behavioral } \\
\text { therapy }\end{array}$ & $\begin{array}{l}\text { Qualitative } \\
\text { observational } \\
\text { study }\end{array}$ & $\begin{array}{l}\text { Group therapy } \\
\text { with follow- } \\
\text { up telephone } \\
\text { consultation }\end{array}$ & $\begin{array}{l}\text { Develop and evaluation of outcomes } \\
\text { of a smoking cessation program with } \\
\text { combination of physiological and } \\
\text { psychological treatment in a group. } \\
\text { Three-month program with } \\
\text { three monthly group sessions, } \\
\text { pharmacotherapy (free nicotine } \\
\text { patches) and telephone counselling. }\end{array}$ & 10 & $\begin{array}{l}\text { Significant reduction in } \% \mathrm{COHB} \\
\text { level and number of cigarettes } \\
\text { smoked at data-point, and in the } \\
\text { number of cigarettes smoked at } \\
\text { one month from the pretest, at } \\
\text { the } 3 \text { months test and at the } 9 \\
\text { months follow-up. At the } 9 \text { months } \\
\text { follow-up, 50\% abstinent rate, } \\
\text { and } 30 \% \text { had decreased cigarette } \\
\text { consumption by at least } 49 \% \\
\text { of their pretest levels. } 80 \% \text { has } \\
\text { changed their smoking behavior. }\end{array}$ & $\begin{array}{l}\text { There is a need for an integrated } \\
\text { group support for smoking } \\
\text { cessation at a larger scale. }\end{array}$ & Moderate \\
\hline 4 & $\begin{array}{l}\text { Avaisu } \\
2011 \\
\text { Malaysia }\end{array}$ & $\begin{array}{l}\text { Face-to-face } \\
\text { behavioral } \\
\text { intervention } \\
\text { for smoking } \\
\text { cessation } \\
\text { Pharmacotherapy } \\
\text { and behavioral } \\
\text { intervention }\end{array}$ & $\begin{array}{l}\text { Non } \\
\text { randomized } \\
\text { quasi- } \\
\text { experimental } \\
\text { study }\end{array}$ & $\begin{array}{l}\text { Effectiveness of } \\
\text { smoking cessation } \\
\text { intervention } \\
\text { among } \\
\text { tuberculosis } \\
\text { patients receiving } \\
\text { SCIDOTS vs } \\
\text { standard care } \\
\text { for TB treatment } \\
\text { (DOTS) }\end{array}$ & $\begin{array}{l}\text { Comparison between conventional } \\
\text { TB DOTS plus smoking cessation } \\
\text { intervention (integrated intervention } \\
\text { or SCIDOTS group) or conventional TB } \\
\text { DOTS alone (comparison or DOTS group) }\end{array}$ & 120 & $\begin{array}{l}120 \text { eligible participants who were } \\
\text { current smokers at the time of TB } \\
\text { diagnosis were assigned to either } \\
\text { of two treatment groups: 7-day } \\
\text { point prevalence abstinence and } \\
\text { continuous abstinence was observed } \\
\text { over time in the intervention group. } \\
\text { At the end of } 6 \text { months, patients } \\
\text { who received the integrated } \\
\text { intervention had significantly } \\
\text { higher rate of success in quitting } \\
\text { smoking when compared with those } \\
\text { who received the conventional TB } \\
\text { treatment alone. }\end{array}$ & $\begin{array}{l}\text { Face-to-face smoking cessation } \\
\text { intervention provided with DOTS } \\
\text { for tuberculosis patients show } \\
\text { that patients who received the } \\
\text { intervention had significantly } \\
\text { higher success rate in quitting } \\
\text { smoking compared to standard care. }\end{array}$ & Moderate \\
\hline
\end{tabular}


Table 1. Continued

\begin{tabular}{|c|c|c|c|c|c|c|c|c|c|}
\hline & $\begin{array}{l}\text { First author, } \\
\text { year of } \\
\text { publication } \\
\text { and country } \\
\text { where } \\
\text { study was } \\
\text { conducted }\end{array}$ & $\begin{array}{c}\text { Role of group } \\
\text { therapy }\end{array}$ & $\begin{array}{l}\text { Types of } \\
\text { study }\end{array}$ & $\begin{array}{c}\text { Treatment type/ } \\
\text { comparison }\end{array}$ & Details of methodology & $\begin{array}{l}\text { Number of } \\
\text { participants }\end{array}$ & Results & Conclusion & $\begin{array}{c}\text { Quality } \\
\text { of } \\
\text { evidence } \\
\text { (Grade) }\end{array}$ \\
\hline 5 & $\begin{array}{l}\text { Siddiqi } \\
2013 \\
\text { Pakistan }\end{array}$ & $\begin{array}{l}\text { Group therapy } \\
\text { in the form of } \\
\text { focus group as } \\
\text { a behavioral } \\
\text { support } \\
\text { Pharmacotherapy } \\
\text { and behavioral } \\
\text { therapy }\end{array}$ & $\begin{array}{l}\text { Cluster } \\
\text { randomized, } \\
\text { controlled } \\
\text { trial }\end{array}$ & $\begin{array}{l}\text { Patient } \\
\text { randomized into } 3 \\
\text { groups [behavioral } \\
\text { support sessions } \\
\text { (BSS), BSS plus } \\
7 \text { weeks of } \\
\text { bupropion therapy } \\
\text { or usual care] } \\
\text { and primary } \\
\text { and secondary } \\
\text { endpoint was } \\
\text { measured. } \\
\text { (Primary end point } \\
\text { was continuous } \\
\text { abstinence at } \\
6 \text { months after } \\
\text { the quit date. } \\
\text { Secondary end } \\
\text { points were point } \\
\text { abstinence at } 1 \\
\text { and } 6 \text { months) }\end{array}$ & $\begin{array}{l}\text { Suspected tuberculosis patients } \\
\text { who come to the health centers } \\
\text { were screened for smoking and } \\
\text { were randomized into } 3 \text { groups (BSS } \\
\text { plus, BSS only and usual care). This } \\
\text { is a balanced, pragmatic, cluster } \\
\text { randomized trial with } 3 \text { groups. Patients } \\
\text { in one group received } 2 \text { brief BSS (BSS } \\
\text { group), patients in the second group } \\
\text { received } 2 \text { brief BSS plus } 7 \text { weeks of } \\
\text { bupropion therapy (BSS group), and } \\
\text { patients in the control group received } \\
\text { usual care. All patients receive self-help } \\
\text { printed materials. }\end{array}$ & 1955 & $\begin{array}{l}\text { Behavioral support, alone or in } \\
\text { combination with bupropion, was } \\
\text { effective in achieving continuous } \\
\text { smoking abstinence at } 6 \text { months } \\
\text { compared with usual care [RR for } \\
\text { BSS plus, } 8.2 \text { (95\% } \mathrm{Cl}: 3.7-18.2) \text {; RR } \\
\text { for BSS, } 7.4 \text { (95\% } \mathrm{Cl}: 3.4-16.4)] \\
\text { Relative risks (RRs) for abstinence } \\
\text { compared with usual care [RR for } \\
\text { BSS plus } 8.2 \text { (95\% Cl: } 3.7-18.2) \text {; RR } \\
\text { for BSS, } 7.4 \text { (95\% Cl: } 3.4-16.4)] \text {. For } \\
\text { continuous abstinence, BSS plus } \\
\text { group achieved higher } 45.4 \% \text { (95\% } \\
\text { Cl: } 41.4-49.4) \text { compared to BSS } \\
\text { (41.0\%). }\end{array}$ & $\begin{array}{l}\text { The estimated cost of behavioral } \\
\text { support ( } \$ 2.50 \text { per participant) was } \\
\text { approximately one tenth that of } \\
\text { behavioral support plus bupropion } \\
\text { ( } \$ 20.90 \text { per participant). Low- and } \\
\text { middle-income countries, where } \\
\text { access to and afford- ability of } \\
\text { medicine is constrained, might } \\
\text { favor an inexpensive non- } \\
\text { pharmacological intervention that } \\
\text { can be delivered by existing staff. } \\
\text { However, BSS+ vs BSS alone in a } \\
\text { non inferiority analysis cannot be } \\
\text { confirmed. BSS can be a Best Buy } \\
\text { to reduce smoking prevalence and } \\
\text { NCDs in low- and middle- income } \\
\text { countries. }\end{array}$ & Moderate \\
\hline 6 & $\begin{array}{l}\text { Sharifi } \\
2012 \\
\text { Iran }\end{array}$ & $\begin{array}{l}\text { Group therapy } \\
\text { as part of } \\
\text { harm reduction } \\
\text { intervention for } \\
\text { smokers in Iran } \\
\text { Pharmacotherapy } \\
\text { and behavioral } \\
\text { therapy }\end{array}$ & $\begin{array}{l}\text { Prospective } \\
\text { cohort study }\end{array}$ & $\begin{array}{l}\text { Patients were } \\
\text { assigned to groups } \\
\text { ( } 5 \text { to } 15 \text { members } \\
\text { in each group) in } \\
\text { conjunction with } \\
\text { the use of nicotine } \\
\text { gum and followed } \\
\text { up at } 2,4,6,8 \\
\text { and } 10 \text { weeks } \\
\text { following study } \\
\text { initiation }\end{array}$ & $\begin{array}{l}\text { The study was conducted for } 12 \text { months } \\
\text { among patients who were unable to } \\
\text { quit. Patients were informed regarding } \\
\text { smoking reduction and abstinence. } \\
\text { Primary outcome was to evaluate } \\
\text { abstinence and smoking reduction at } \\
\text { the third and sixth months of follow- } \\
\text { up: the number of smoked cigarettes, } \\
\text { level of expired carbon monoxide (CO), } \\
\text { and numbers of nicotine gum used. }\end{array}$ & 132 & $\begin{array}{l}64.4 \% \text { of the study participants } \\
\text { reduced the number of daily } \\
\text { smoked cigarettes by at least } 50 \% \\
\text { and } 12.9 \% \text { quit smoking at } 6 \\
\text { months. }\end{array}$ & $\begin{array}{l}\text { Smoking reduction and abstinence } \\
\text { can be achieved by prolonged } \\
\text { counselling and NRT. Smoking } \\
\text { reduction is a useful method for } \\
\text { smokers who are unable to stop } \\
\text { smoking immediately. }\end{array}$ & Low \\
\hline
\end{tabular}


Table 1. Continued

\begin{tabular}{|c|c|c|c|c|c|c|c|c|c|}
\hline & $\begin{array}{l}\text { First author, } \\
\text { year of } \\
\text { publication } \\
\text { and country } \\
\text { where } \\
\text { study was } \\
\text { conducted }\end{array}$ & $\begin{array}{c}\text { Role of group } \\
\text { therapy }\end{array}$ & $\begin{array}{l}\text { Types of } \\
\text { study }\end{array}$ & $\begin{array}{l}\text { Treatment type/ } \\
\text { comparison }\end{array}$ & Details of methodology & $\begin{array}{c}\text { Number of } \\
\text { participants }\end{array}$ & Results & Conclusion & $\begin{array}{c}\text { Quality } \\
\text { of } \\
\text { evidence } \\
\text { (Grade) }\end{array}$ \\
\hline 7 & $\begin{array}{l}\text { Lee } \\
2017 \\
\text { South Korea }\end{array}$ & $\begin{array}{l}\text { Group therapy } \\
\text { for positive } \\
\text { psychotherapy } \\
\text { and motivational } \\
\text { interviewing as } \\
\text { an intervention } \\
\text { for smoking } \\
\text { cessation } \\
\text { Behavioral } \\
\text { therapy only }\end{array}$ & $\begin{array}{l}\text { Observational } \\
\text { Qualitative } \\
\text { study }\end{array}$ & $\begin{array}{l}\text { Positive group } \\
\text { psychotherapy } \\
\text { and motivational } \\
\text { interviewing were } \\
\text { attended by } 36 \\
\text { smokers for } 1 \text { hour } \\
\text { once a week, for } 6 \\
\text { hours (with a total } \\
\text { of } 6 \text { sessions in } 6 \\
\text { weeks) followed } \\
\text { by follow-up at } \\
3 \text { months and } \\
\text { at } 6 \text { months. An } \\
\text { interview was } \\
\text { conducted after } \\
\text { the intervention } \\
\text { was completed }\end{array}$ & $\begin{array}{l}36 \text { study subjects were recruited. } \\
\text { The importance of smoking cessation } \\
\text { was higher among the group of } \\
\text { participants who managed to } \\
\text { successfully quit smoking at } 3 \text { months } \\
\text { ( } \mathrm{n}=10 \text { ) and participants who did not } \\
\text { have a successful quit attempt at } 3 \\
\text { months ( } \mathrm{n}=26 \text { ) }\end{array}$ & 36 & $\begin{array}{l}\text { The confidence to stop smoking } \\
\text { was rated higher by the success } \\
\text { ( }<<0.01) \text {. The reason for a successful } \\
\text { quit attempt was for their loved } \\
\text { ones }(60 \%) \text { and health }(50 \%) \text {. The } \\
\text { unsuccessful group wanted to stop } \\
\text { smoking to save money }(45.5 \%) \text {. } \\
\text { The unsuccessful group had more } \\
\text { than } 1 \text { cross addiction compared to } \\
\text { successful group. They also had less } \\
\text { participants with } 10 \text { best personal } \\
\text { merits than the successful group. }\end{array}$ & $\begin{array}{l}\text { The importance of motivation and } \\
\text { confidence in smoking cessation } \\
\text { were predictors for successful } \\
\text { cessation. Motivational interviewing } \\
\text { increased motivations, whereas } \\
\text { positive group psychotherapy } \\
\text { increased positive thoughts and } \\
\text { confidence, which are essential for a } \\
\text { successful quit attempt. }\end{array}$ & Low \\
\hline
\end{tabular}


Table 1. Continued

\begin{tabular}{|c|c|c|c|c|c|c|c|c|c|}
\hline & $\begin{array}{l}\text { First author, } \\
\text { year of } \\
\text { publication } \\
\text { and country } \\
\text { where } \\
\text { study was } \\
\text { conducted }\end{array}$ & $\begin{array}{c}\text { Role of group } \\
\text { therapy }\end{array}$ & $\begin{array}{l}\text { Types of } \\
\text { study }\end{array}$ & $\begin{array}{l}\text { Treatment type/ } \\
\text { comparison }\end{array}$ & Details of methodology & $\begin{array}{l}\text { Number of } \\
\text { participants }\end{array}$ & Results & Conclusion & $\begin{array}{c}\text { Quality } \\
\text { of } \\
\text { evidence } \\
\text { (Grade) }\end{array}$ \\
\hline 8 & $\begin{array}{l}\text { Hotta } \\
2007 \\
\text { Japan }\end{array}$ & $\begin{array}{l}\text { Effectiveness of } \\
\text { group therapy } \\
\text { in university } \\
\text { and workplace } \\
\text { environment to } \\
\text { assist smokers to } \\
\text { quit smoking } \\
\text { Pharmacotherapy } \\
\text { and behavioral } \\
\text { therapy }\end{array}$ & $\begin{array}{l}\text { Cross- } \\
\text { sectional } \\
\text { study }\end{array}$ & $\begin{array}{l}\text { Testing the } \\
\text { efficacy of group } \\
\text { therapy for the } \\
\text { participants } \\
\text { who want to } \\
\text { quit smoking } \\
\text { in Okayama } \\
\text { University, Japan. } \\
\text { This program } \\
\text { consisted of } \\
\text { behavioral } \\
\text { support, nicotine } \\
\text { patches and } \\
\text { online support. } \\
\text { Smoking status } \\
\text { was assessed by } \\
\text { direct interviews. } \\
\text { A total of } 7 \text { visits } \\
\text { of counselling and } \\
\text { medication were } \\
\text { provided. }\end{array}$ & $\begin{array}{l}\text { A total of } 102 \text { employees were enrolled } \\
\text { in the cessation program, which } \\
\text { corresponding to } 20.4 \% \text { of the total } \\
\text { smokers in the university. Majority } \\
\text { were male, aged } \geq 20 \text { years, smoked } 23 \\
\text { cig/day, had moderate dependence to } \\
\text { nicotine and had median of } 16 \mathrm{ppm} \text { in } \\
\text { CO Smokerlyzer reading. }\end{array}$ & 102 & $\begin{array}{l}\text { Out of the } 102 \text { participants, } 1 \\
\text { refused to participate in the study } \\
\text { after registering, } 7 \text { did not turn up } \\
\text { for follow-up after } 1 \text { year. } 53 \% \\
\text { of the remaining } 94 \text { participants } \\
\text { had obtained abstinence. In the } \\
\text { intention-to-treat group, where } \\
\text { participants who were lost from } \\
\text { follow-up are considered as } \\
\text { smoking, the cessation rate was } \\
\text { calculated as } 50 \%(50 / 101) \text {. }\end{array}$ & $\begin{array}{l}\text { Type of position was a significant } \\
\text { factor affecting the } 1 \text {-year } \\
\text { cessation rates with } 78 \%, 55 \% \text { and } \\
6 \% \text { in the academic, administrative } \\
\text { and technical staff. } \\
\text { It was reported that type of position } \\
\text { at workplace and sending email } \\
\text { within the first week of cessation } \\
\text { attempt was a significant factor } \\
\text { affecting the } 1 \text {-year cessation rates. }\end{array}$ & Moderate \\
\hline
\end{tabular}


Table 1. Continued

\begin{tabular}{|c|c|c|c|c|c|c|c|c|c|}
\hline & $\begin{array}{l}\text { First author, } \\
\text { year of } \\
\text { publication } \\
\text { and country } \\
\text { where } \\
\text { study was } \\
\text { conducted }\end{array}$ & $\begin{array}{c}\text { Role of group } \\
\text { therapy }\end{array}$ & $\begin{array}{l}\text { Types of } \\
\text { study }\end{array}$ & $\begin{array}{l}\text { Treatment type/ } \\
\text { comparison }\end{array}$ & Details of methodology & $\begin{array}{l}\text { Number of } \\
\text { participants }\end{array}$ & Results & Conclusion & $\begin{array}{c}\text { Quality } \\
\text { of } \\
\text { evidence } \\
\text { (Grade) }\end{array}$ \\
\hline 9 & $\begin{array}{l}\text { Pimple } \\
2014 \\
\text { India }\end{array}$ & $\begin{array}{l}\text { Behavioral } \\
\text { intervention } \\
\text { (individual + } \\
\text { group therapy) } \\
\text { for smoking } \\
\text { cessation at } \\
\text { workplace } \\
\text { Behavioral } \\
\text { therapy only }\end{array}$ & $\begin{array}{l}\text { Cross- } \\
\text { sectional } \\
\text { study }\end{array}$ & $\begin{array}{l}\text { There were } 3 \\
\text { sessions provided } \\
\text { for a duration } \\
\text { of } 6 \text { months (0, } \\
3,6 \text { ). Workers } \\
\text { are divided into } \\
\text { groups with a } \\
\text { limit of 15-45 } \\
\text { persons per group. } \\
\text { The sessions were } \\
\text { conducted under } \\
\text { the principles of } \\
\text { group therapy. } \\
\text { The sessions } \\
\text { were: supportive } \\
\text { psychotherapy, } \\
\text { cognitive behavior } \\
\text { therapy, and } \\
\text { psychodrama. } \\
\text { There was no } \\
\text { pharmacotherapy } \\
\text { provided. } \\
\text { The attrition rate } \\
\text { of } 78.6 \% \text { (176) } \\
\text { was achieved. }\end{array}$ & $\begin{array}{l}\text { Majority of the participants were } \\
\text { in precontemplation phase. After } 3 \\
\text { months, } 59 \text { users remained at the } \\
\text { contemplation phase, and an increase } \\
\text { from } 21 \text { to } 52 \text { for preparation, from } \\
21 \text { to } 95 \text { for action and maintenance, } \\
\text { and } 6 \text { relapsed, compared to post- } \\
\text { intervention assessment. } \\
\text { At } 6 \text { months, } 57 \text { participants remained } \\
\text { at the contemplation phase, while } \\
\text { the number decreased to } 45 \text { for } \\
\text { preparation, from } 95 \text { to } 38 \text { for action } \\
\text { and maintenance, and } 36 \text { relapsed, } \\
\text { compared to post- intervention II } \\
\text { assessment. } \\
\text { Factors such as sociodemographic } \\
\text { characteristics and smoking status did } \\
\text { not influence the intention to quit, } \\
\text { however, presence of pre-cancerous } \\
\text { oral lesions during screening has been } \\
\text { found to be a factor for quit attempt. } \\
\text { Like age, gender, education, income, } \\
\text { marital status, religion, alcohol use, } \\
\text { personal medical history, Fagerström } \\
\text { score, previous quit attempts, forms } \\
\text { of tobacco use, withdrawal symptoms } \\
\text { experienced and family members } \\
\text { tobacco history had no bearing on their } \\
\text { intent and decision to quit. In contrast, } \\
\text { presence of clinical oral pre-cancer } \\
\text { lesions found to be associated with } \\
\text { quitting. }\end{array}$ & 224 & $\begin{array}{l}\text { Majority of the workers, } 95(42.4 \%) \text {, } \\
\text { who successfully quit in the initial } \\
\text { stages post second intervention } \\
\text { program were not able to follow } \\
\text { the linear path to maintenance. } \\
\text { The current study witnessed around } \\
6(2.7 \%) \text { followed by } 36(16.1 \%) \\
\text { workers relapsing at the end of } \\
\text { second and third (last) intervention } \\
\text { sessions. Extended cessation } \\
\text { therapies with relapse prevention } \\
\text { strategies may help combat the } \\
\text { problem. }\end{array}$ & $\begin{array}{l}\text { Behavioral intervention at } \\
\text { workplace is a cost- effective tool } \\
\text { to help smokers to quit smoking. } \\
\text { increase the likelihood of quitting. } \\
\text { Employers can maintain a smoke- } \\
\text { free workplace by promoting } \\
\text { tobacco control measures for overall } \\
\text { health benefits of the employees }\end{array}$ & Low \\
\hline
\end{tabular}


Figure 2. Forest plot of intervention study by Awaisu 2011 and Siddiqi 2013 on behavioral therapy with pharmacotherapy versus usual care in tuberculosis patients: effect on continuous abstinence of smoking at 6 months

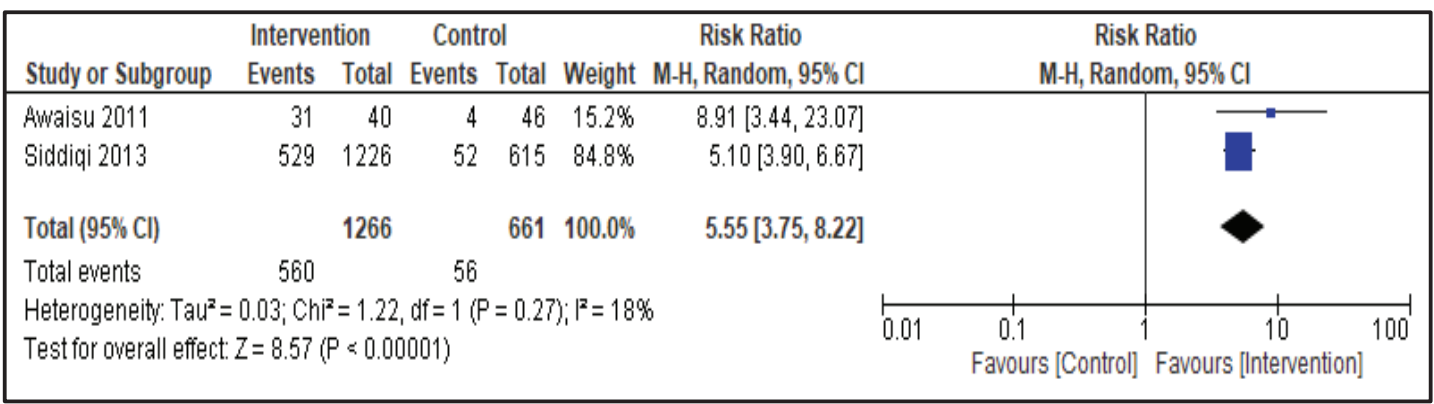

two groups. However, a heterogeneity analysis was conducted and there was no significant heterogeneity: $I^{2}=18 \%(p=0.27)$ (Figure 2).

\section{DISCUSSION}

Our review identified an important finding in the treatment for cigarette smoking for smokers in Asian countries. The availability of group therapy as an alternative to individual therapy (standard care) provides a treatment option for smokers to choose when a smoker decides to quit smoking. Furthermore, evidence has shown that group therapy provides better outcomes compared to minimal intervention or no intervention. Despite the evidence published in the western population, we found only a handful of articles relevant to our question of interest, which was the availability of group therapy for smoking cessation in Asian countries (Table 1). The studies looked at the use of group therapy in various circumstances such as group therapy + pharmacotherapy, counselling in the form of group therapy, and the treatment outcome.

Most of the studies selected in this systematic review were conducted in middle-income (Malaysia, Pakistan, India, Mongolia, Iran) and high-income countries (Japan, South Korea). In general, less wealthy countries have fewer resources to invest in smoking cessation than higher income countries. Despite this, smokers in poorer countries had no less interest in quitting smoking. Although smokers in middle-income countries were reported to have lower use of quit smoking medication and healthcare services, it does not translate to less interest in quitting. In Malaysia, smokers are keen to respond to healthcare queries on smoking behaviours ${ }^{7}$. This is important, because $80 \%$ of the world's smokers are from low- and middle-income countries and it is estimated that 7 million deaths attributable to smoking will occur by $2030^{15}$.

Huang et al. ${ }^{34}$ reported high abstinence, reduced number of cigarettes smoked and change in smoking behavior in group intervention with pharmacotherapy. Meanwhile, Siddiqi et al. ${ }^{36}$ found that group therapy alone or in combination with pharmacotherapy (e.g. bupropion) was effective. Sharifi et al. ${ }^{37}$ reported that counselling and pharmacotherapy can achieve smoking abstinence and reduction of the number of cigarettes smoked per day, as the smoking reduction was found to be a useful method for smokers who are unable to stop smoking immediately. Despite their potential among Asian smokers, group-based interventions for smoking cessation are underresearched. In other settings, studies have shown group-based treatment interventions to be effective. Group treatment that included medication such as varenicline, NRT, and bupropion, or bupropion + NRT, decreased the number of cigarettes smoked per day in a single group behavioral support ${ }^{39}$. Our results align with those of reviews in western nations, such as studies by Prochaska et al. ${ }^{40}$ and Schlam et al. ${ }^{41}$, in which behavioral support with pharmacotherapy increased cessation rates and improved long-term abstinence, but most smokers eventually relapsed.

Combining behavioral interventions such as counselling and pharmacotherapy for smoking cessation helps smokers in their quit attempt and the outcome is better than counselling alone, even if the counselling is provided by healthcare professionals. Behavioral support with pharmacotherapy increased 
cessation rates and improved long-term abstinence, but most smokers eventually relapsed ${ }^{42}$. There should be monitoring and supervision by healthcare professionals and the management should be collaborative work between doctors and nurses. Quit smoking initiatives at universities and workplaces have proven to be an effective setting for early quit attempts ${ }^{43}$ and should be explored in Asian nations. Employers should not only promote smokefree workplaces and provide incentives to motivate smokers to quit smoking, but also introduce group counselling to help employees quit cigarette smoking.

\section{CONCLUSIONS}

Despite its potential and some evidence of benefit, research on group-based interventions for smoking cessation in Asian countries is lacking. Direct oneto-one comparisons between group therapy and individual therapy in behavioral support for smokers who want to quit smoking are needed. Innovative setting-based studies are also needed, such as those exploring the potential of workplaces and other group settings. Such evidence, based on the efficacy, affordability and feasibility of group therapy for smoking cessation among Asian smokers, would then support country-specific national guidelines to optimize country-specific and cost-effective smoking cessation initiatives. The practical implication identified in this systematic review on group therapy is that it can increase the likelihood of quitting cigarette smoking when the person is motivated in joining the group therapy. Group therapy can become a comprehensive extension of standard care available in most healthcare system. The impact of group therapy can become meaningful depending on the uptake so that the benefit of group therapy such as cost-effectiveness can be observed and documented. For research implications related to this systematic review, a larger number of participants in group therapy for smoking cessation would be desired to identify the impact of specific components in group therapy research and its efficacy.

\section{REFERENCES}

1. Drope J, Schluger N, Gahn Z, et al. The Tobacco Atlas. American Cancer Society and Vital Strategies; 2018. Accessed February 2, 2021. https://tobaccoatlas.org/ wp-content/uploads/2018/03/TobaccoAtlas_6thEdition_
LoRes_Rev0318.pdf

2. Rose CA, Hilton MJ, Sweanor T, Henningfield J. Smoking: tobacco. In: Encyclopedia Britannica. November 19, 2020. Accessed February 2, 2021. https://www.britannica.com/ topic/smoking-tobacco

3. Aung MN, Motoyuki Y, Moolphate S, et al. Effectiveness of a new multi-component smoking cessation service package for patients with hypertension and diabetes in northern Thailand: a randomized controlled trial (ESCAPE study). Subst Abuse Treat Prev Policy. 2019;14(1):10. doi:10.1186/s13011-019-0197-2

4. Nargis N, Yong HH, Driezen P, et al. Socioeconomic patterns of smoking cessation behavior in low and middle-income countries: Emerging evidence from the Global Adult Tobacco Surveys and International Tobacco Control Surveys. PLoS One. 2019;14(9):e0220223. doi:10.1371/journal.pone.0220223

5. World Health Organization. WHO Report on the Global Tobacco Epidemic, 2017: Monitoring tobacco use and prevention policies. World Health Organization; 2017. Accessed February 2, 2021. https://apps.who.int/iris/ bitstream/handle/10665/255874/9789241512824-eng. pdf? sequence $=1 \&$ isAllowed $=y$

6. Baigalmaa D, Nishimura A, Katsuki I. Smoking cessation rate 12 months after a group counseling program in Mongolia. Asian Pac J Cancer Prev. 2006;7(3):399-402. Accessed February 2, 2021. http://journal.waocp.org/ article_24490_0decedfbb250fad1ad178227f7c1e89e.pdf

7. Borland R, Li L, Driezen P, Wilson N, Hammond D, Thompson ME. Cessation assistance reported by smokers in 15 countries participating in the International Tobacco Control (ITC) policy evaluation surveys. Addiction. 2012;107(1):197-205. doi:10.1111/j.1360-0443.2011.03636.x

8. Burns PB, Rohrich RJ, Chung KC. The levels of evidence and their role in evidence-based medicine. Plast Reconstr Surg. 2011;128(1):305-310. doi:10.1097/PRS.0b013e318219c171

9. GBD 2015 Tobacco Collaborators. Smoking prevalence and attributable disease burden in 195 countries and territories, 1990-2015: a systematic analysis from the Global Burden of Disease Study 2015. Lancet. 2017;389(10082):18851906. doi:10.1016/S0140-6736(17)30819-X

10. Dautzenberg B, Dautzenberg MD. Le tabac chauffé: revue systématique de la littérature. \{Systematic analysis of the scientific literature on heated tobacco]. Article in French. Rev Mal Respir. 2019;36(1):82-103. doi:10.1016/j.rmr.2018.10.010

11. The ASEAN Tobacco Control Report. Vietnam Steering Committee on Smoking and Health, Southeast Asia Tobacco Control Alliance; 2014. Accessed February 2, 2021. https://asean.org/storage/2017/02/Agd-7.2_ HP2a_Malaysia_ASEAN-TC-report-2014_Final.pdf

12. Yang JJ, Yu D, Wen W, Shu XO, Eiko S, Rahman S. Tobacco Smoking and Mortality in Asia: A Pooled Meta-analysis. JAMA Netw Open. 2019;2(3):e191474. 
doi:10.1001/jamanetworkopen.2019.1474

13. Ditchburn KM, Caldwell B, Crane J. Smoking cessation is a prolonged journey rather than a single trip. $\mathrm{N} Z \mathrm{Z}$ Med J. 2012;125(1364):91-97. Accessed February 2, 2021. https://assets-global.website-files.com/5e332a62c703f6 53182faf47/5e332a62c703f644992fdd20_ditchburn.pdf

14. Hotta K, Kinumi K, Naito K, et al. An intensive group therapy programme for smoking cessation using nicotine patch and internet mailing supports in a university setting. Int J Clin Pract. 2007;61(12):1997-2001. doi:10.1111/j.1742-1241.2007.01466.x

15. Jha P, Peto R. Global effects of smoking, of quitting, and of taxing tobacco. N Engl J Med. 2014;370(1):60-68. doi:10.1056/NEJMra1308383

16. Jiloha RC. Pharmacotherapy of smoking cessation. Indian J Psychiatry. 2014:56(1):87-95. doi:10.4103/0019-5545.124726

17. Khara M, Chizimuzo TCO. A retrospective review of pilot outcomes from an out-patient tobacco treatment programme within cardiology services. J Smok Cessat. 2015;10(1):74. doi:10.1017/jsc.2013.40

18. Lindson-Hawley N, Thompson TP, Begh R. Motivational interviewing for smoking cessation. Cochrane Database Syst Rev. 2015;(3):CD006936. doi:10.1002/14651858.CD006936.pub3

19. Michie S, Hyder N, Walia A, West R. Development of a taxonomy of behaviour change techniques used in individual behavioural support for smoking cessation. Addict Behav. 2011;36(4):315-319. doi:10.1016/j.addbeh.2010.11.016

20. Kishore SP, Bitton A, Cravioto A, et al. Enabling access to new WHO essential medicines: the case for nicotine replacement therapies. Global Health. 2010;6(1):22. doi:10.1186/1744-8603-6-22

21. Papadakis S, Aitken D, Gocan S, et al. A randomised controlled pilot study of standardised counselling and cost-free pharmacotherapy for smoking cessation among stroke and TIA patients. BMJ Open. 2011;1(2):e000366. doi:10.1136/bmjopen-2011-000366

22. Stead LF, Lancaster T. Group behaviour therapy programmes for smoking cessation. Cochrane Database Syst Rev. 2000;(2):CD001007. doi:10.1002/14651858.CD001007

23. Valera P, Acuna N, Vento I. The Preliminary Efficacy and Feasibility of Group-Based Smoking Cessation Treatment Program for Incarcerated Smokers. Am J Mens Health. 2020;14(4):1557988320943357. doi:10.1177/1557988320943357

24. Pimple S, Pednekar M, Mazumdar P, Goswami S, Shastri S. Predictors of quitting tobacco--results of a worksite tobacco cessation service program among factory workers in Mumbai, India. Asian Pac J Cancer Prev. 2012;13(2):533-538. doi:10.7314/apjcp.2012.13.2.533

25. West R, Raw M, McNeill A, Stead L, Aveyard P, Bitton J. Health-care interventions to promote and assist tobacco cessation: a review of efficacy, effectiveness and affordability for use in national guideline development. Addiction.
2015;110(9):1388-1403. doi:10.1111/add.12998

26. Piper ME, Bullen C, Krishnan-Sarin S, et al. Defining and Measuring Abstinence in Clinical Trials of Smoking Cessation Interventions: An Updated Review. Nicotine Tob Res. 2020;22(7):1098-1106. doi:10.1093/ntr/ntz110

27. Hall SM, Humfleet GL, Reus VI, Muñoz RF, Cullen J. Extended nortriptyline and psychological treatment for cigarette smoking. Am J Psychiatry. 2004;161(11):21002107. doi:10.1176/appi.ajp.161.11.2100

28. Lai DT, Cahill K, Qin Y, Tang JL. Motivational interviewing for smoking cessation. Cochrane Database Syst Rev. 2010;(1):CD006936. doi:10.1002/14651858.CD006936.pub2

29. Aubin HJ, Karila L, Reynaud M. Pharmacotherapy for smoking cessation: present and future. Curr Pharm Des. 2011;17(14):1343-1350. doi:10.2174/138161211796150837

30. Page MJ, McKenzie JE, Bossuyt PM, et al. The PRISMA 2020 statement: an updated guideline for reporting systematic reviews. Systematic Reviews. 2021;10(1):89. doi:10.1186/s13643-021-01626-4

31. National Institute for Health Research. PROSPERO is fasttracking registration of protocols related to COVID-19. Centre for Reviews and Dissemination, University of York; 2020. Accessed February 2, 2021. https://www.crd.york. ac.uk/prospero/

32. Higgins JPT, Savović J, Page MJ, Elbers RG, Sterne JAC. Chapter 8: Assessing risk of bias in a randomized trial. In: Higgins JPT, Thomas J, Chandler J, Cumpston M, Li T, Page MJ, Welch VA, eds. Cochrane Handbook for Systematic Reviews of Interventions. Version 6.2. Updated February 2021. Accessed May 8, 2021. www. training.cochrane.org/handbook

33. Maarof MF, Mhd AA, Amit N, Bakry MM, Taha NA. Suitability of a Group Behavioural Therapy Module for Workplace Smoking Cessation Programs in Malaysia: a Pilot Study. Asian Pac J Cancer Prev. 2016;17(1):207214. doi:10.7314/apjcp.2016.17.1.207

34. Huang CL. Evaluating the program of a smoking cessation support group for adult smokers: a longitudinal pilot study. J Nurs Res. 2005;13(3):197-205. doi:10.1097/01.jnr.0000387541.83630.71

35. Avaisu A, Mohamad HNM, Noorliza M. The SCIDOTS Project: Evidence of benefits of an integrated tobacco cessation intervention in tuberculosis care on treatment outcomes. Substance Abuse Treatment, Prevention and Policy. 2011;6:26. doi:10.1186/1747-597X-6-26

36. Siddiqi K, Khan A, Ahmad M, et al. Action to stop smoking in suspected tuberculosis (ASSIST) in Pakistan: a cluster randomized, controlled trial. Ann Intern Med. 2013;158(9):667675. doi:10.7326/0003-4819-158-9-201305070-00006

37. Sharifi H, Kharaghani R, Emami H, Hessami Z, Masjedi MR. Efficacy of harm reduction programs among patients of a smoking cessation clinic in Tehran, Iran. Arch Iran Med. 2012;15(5):283-289. Accessed February 2, 2021. 
http://www.ams.ac.ir/AIM/NEWPUB/12/15/5/008.pdf

38. Lee EJ. The Effect of Positive Group Psychotherapy and Motivational Interviewing on Smoking Cessation: A Qualitative Descriptive Study. J Addict Nurs. 2017;28(2):88-95. doi:10.1097/JAN.0000000000000169

39. Gould GS, Watters T. Are Single-session Smoking Cessation Groups a Feasible Option for Rural Australia? - Outcomes From a Pilot Study. J Smoking Cessation. 2015;10(2):135-140. doi:10.1017/jsc.2014.4

40. Prochaska JJ, Neal LB. The Past, Present, and Future of Nicotine Addiction Therapy. Annu Rev Med. 2016;67(1):467486. doi:10.1146/annurev-med-111314-033712

41. Schlam TR, Baker TB. Interventions for tobacco smoking. Annu Rev Clin Psychol. 2013;9(1):675-702. doi:10.1146/annurev-clinpsy-050212-185602

42. García-Rodríguez O, Secades-Villa R, Flórez-Salamanca L, Okuda M, Liu SM, Blanco C. Probability and predictors of relapse to smoking: results of the National Epidemiologic Survey on Alcohol and Related Conditions (NESARC). Drug Alcohol Depend. 2013;132(3):479-485. doi:10.1016/j.drugalcdep.2013.03.008

43. Swayampakala K, Thrasher J, Carpenter MJ, Shigematsu LMR, Cupertio AP, Berg CJ. Level of cigarette consumption and quit behavior in a population of low-intensity smokers-longitudinal results from the International Tobacco Control (ITC) survey in Mexico. Addict Behav. 2013;38(4):19581965. doi:10.1016/j.addbeh.2012.12.007
CONFLICTS OF INTEREST

The authors have each completed and submitted an ICMJE form for disclosure of potential conflicts of interest. The authors declare that they have no competing interests, financial or otherwise, related to the current work. C. Bullen reports grants to his institution from the Education NZ, from The Health Research Council of NZ, from MAS Foundation NZ, from Tencent China and from WHO. Also he reports contracts to his institution from the NZ Ministry of Health, from Pfizer Upjohn (Aust), and from the NZ Ministry of Foreign Affairs and Trade. In addition he reports consultancy fee from J\&J Japan on NRT and payment for an invited presentation to the 13th Annual Ottawa Conference (Tobacco Treatment) and attendance fees (Health Research Council Public Health Advisory Committee), and that he is President of the Society for Research on Nicotine \& Tobacco-Oceania (unpaid position). A.S. Amer Nordin reports that this study was supported by Universiti Malaya Grand Challenge grants GC004-15HTM and GC004C-15HTM and that he received honoraria for lectures and an unconditional educational grant from Johnson \& Johnson Malaysia. He also reports that he is a member of the Technical Working Group for Tobacco Control (unpaid position)

\section{FUNDING}

This research was funded through a Universiti Malaya Grand Challenge grants GC004-15HTM and GC004C-15HTM.

\section{ETHICAL APPROVAL AND INFORMED CONSENT}

Ethical approval and informed consent were not required for this review.

\section{DATA AVAILABILITY}

The data supporting this study are available from the authors on reasonable request.

\section{AUTHORS' CONTRIBUTIONS}

Conceptualization: RM and ASAN. Methodology: RM and CB. Writing and original draft preparation: RM. Writing, review and editing: RM, ASAN and CB. Supervision: CB and ASAN. All authors have read and agreed to the published version of the manuscript.

PROVENANCE AND PEER REVIEW

Not commissioned; externally peer reviewed. 